\title{
An Audit Remark on Malaysian Local Authorities Immovable Asset Management
}

\author{
Nur Berahim (Corresponding author) \\ Department of Real Estate, Faculty of Geoinformation and Real Estate \\ University Technology Malaysia, Johor, Malaysia \\ E-mail: nurberahim@gmail.com \\ Mohd Nadzri Jaafar \& Ainur Zaireen Zainudin \\ Department of Real Estate, Faculty of Geoinformation and Real Estate \\ University Technology Malaysia, Johor, Malaysia
}

Received: August 25, 2014

doi:10.5296/jmr.v7i2.6948
Accepted: November 20, 2014 Published: February 1, 2015

URL: http://dx.doi.org/10.5296/jmr.v7i2.6948

\begin{abstract}
The management activities of the local authorities were audited to evaluate whether the planning of programs and activities was carried out successfully within the stipulated period, without any wastage. Generally, any issues or weaknesses of activities will be revealed by the audit. Thus, the outcome of the audit will assist local authorities to take corrective action on the issues raised so that value for money could be obtained. The objective of this paper is to review what are the issues that frequently be raised by the audit on local authorities' immovable assets. A total of 13 projects were reviewed through the Auditor General Report on the activities of State Government Department and Agencies from 2011 to 2013. The review only involved projects on local authorities' immovable property. Document analysis method was used to know the evaluation done by the Malaysian National Audit Department of the local authority property management over the years. Out of 13 projects being reviewed, it can be concluded that there were seven main matters that have caused a lot of money being wasted for namely high arrears of rental and tax revenue, poor maintenance, vandalism and theft activities, delayed project, poor documentation, record and system, abandoned and unutilized asset also weak monitoring and enforcement by the council on property. Factors were interrelated to each other make more money to be spent in managing a property. In conclusion, property management in Local authorities is still in unsatisfactory level. Comments issued by the National Audit Department may be a best guideline for
\end{abstract}




\section{Macrothink}

Journal of Management Research ISSN 1941-899X 2015, Vol. 7, No. 2

improvements. This paper proposed further research to be undertaken into property management issues based on category of immovable property.

Keywords: Audit remark, Local authority immovable asset, Weaknesses 


\section{Introduction}

Immovable properties such as land, building and infrastructure are valuable resources that directly influence the revenue and expenditure of local authorities. These immovable properties represent as one key factor for adequate financial source in local authorities. In general, as observed from Soeb et al (2011) and Thenmolli and Kuppusamy (2013), local authorities' finance is a serious issue that affects the operation of local authorities in Malaysia. Due to big money involved in creating these immovable assets, local government need to ensure that they could obtain a reasonable return on the investment that has been made. But in practice, there are lots of properties that do not generate worthwhile income to local authorities for many reasons as reported by auditor. As highlighted by National Audit Department (2011), from audit reports, it is not uncommon that instances of wastefulness, extravagance and mismanagement have been detected which indicate that public money has not been wisely spent. Therefore it is essential to explore the factors that impede the achievement of valuable return form immovable assets activities in local government agencies.

In Malaysia, National Audit Department (NAD) is the government agency that responsible for yearly evaluation of the local authorities' financial and management performance. According to Danilah and Siti Nabihah (2011), the issues of inefficiency and ineffectiveness of local authorities have been addressed by politicians and public via electronic and written media. The audit body was also not spared in discussion on issues related to inefficient local authorities' property management activities. In general, the establishment of National Audit Department of Malaysia was an effort to strengthen financial management of the public sector administration and to ensure all government rules and procedures have been implemented and complied with (National Audit Department, 2007).

In United Kingdom (UK), the Audit Commission plays an important role by reporting on local government performance in the management of assets. The challenge faced by local government agency was discussed as early in 1988 by the UK Audit Commission that highlighted the problem faced by local authorities in managing property. In relation, UK Audit Commission has published two major reports called 'A Management Handbook' and 'A Management Overview' that highly critic the management of local authorities' property. UK Audit Commission (1988) emphasized the fact that things surround the local authority are changing but the local authority itself are not changing fast enough. In other reports, Audit Commission (2000) adds that too many authorities devote insufficient attention to use and cost of their assets, resulting in money being wasted and substandard service delivery to users. Incapability of local authority in managing the property agreed by many scholars bring a huge loses of the limited finance.

In Malaysian practice, National Audit Department does not specifically involve in performance evaluation of the assets owned by the local authorities. In contrast to international practice like in the UK and Australia, there is no special report on the performance of the local authorities' property management that has been proposed by the National Audit Department in Malaysia. However, if the Auditor General's Report regarding 
the management activities of the Government Department or Agencies is reviewed, issues related to local authorities' property management problems that leading to loss of value can be identified. Thereby, this study covers the performance audit by Auditor General in evaluating whether the programmes and activities of the local authorities in Peninsular Malaysia have been carried out economically, efficiently and effectively to achieve its desired objectives and goals. The aim of this study therefore is to identify the issues that be raised by the audit report on local authority's project regard with immovable assets. Understanding issues will help these public bodies to design value-adding strategies and the development of alternative solutions to ensure that immovable property under the management of local authorities could bring good financial return.

\section{Review of Literature}

Local authorities nowadays faced great challenge as self-financing organization. Thereby, local authorities are requires to generate enough income to support operational activities of council and service provision to public. However, limited financial is always become a major constraint to local authorities as frequently being discussed by previous scholars (Dent, 2002; Jolicoeur and Barret, 2004; Nafsiah Mohamed and Ruhaya Atan, 2006; Bovaird and Loffler, 2002). In a study on Malaysian local authorities' financial performance by Ruhaya Atan et al (2010), it is found that local authorities were not creating enough income in relation to their expenditure and it is possible that this shortfalls may continue in the near future if no necessary action is taken. Without adequate financial sources, it is difficult for local authorities to fulfill duties as service provider and a facilitator of socio economic growth for public. Thus, one of the efforts to strengthen local authorities' revenue is through an effective asset management especially on immovable asset. An effective use of asset may significantly contribute to increase in local authorities revenues.

Assets are important strategic resources to the country which are expensive to build, maintain and manage through time (National Audit Department, 2011). Assets belong to local authority are closely linked to the financial capability of the organization. A good property management can improve council's income or vice versa will cause a lot of money being wasted due to mismanagement. According to Constantin et al (2011), two main financial goal of local government property is to maximizing efficient use of property and cutting cost of properties. Phelps (2009) views that; the nature of property management in local government is changing from a traditional role of 'paternalistic stewardship' to 'commercial exploitation' on its portfolio. Nowadays, property is simply recognized as a strategic resource and as a 'productive asset' rather than a 'public good'.

However, according to National Audit Department (2011), audit report over the year contain horror stories about how inefficient or ineffective the manner in which government asset are acquired, managed, maintained and disposed. Subsequently, much money has gone wasted. Based on the research from Ghobadian dan Ashworth (1994), the Audit Commission argued that the performance in local authorities consisted of two key elements which are efficiency and effectiveness. Service efficiency is defined as the provision of specified volume and quality of service with the lowest level of resources capable of meeting that specification. 
Meanwhile, service effectiveness is defined as providing the right services to enable the local authority to implement its policies and objectives. For example, an audit on the procurement and asset management of local authorities in Perak carried out for the year 2009 and 2011 has discovered the issues of ineffective and inefficient of property management. Some weaknesses summarized by Auditor General's Report of Perak State (2011) was delay in construction projects, facilities and completed buildings were not used, abandoned buildings were not maintained, management of rental contract was not satisfactory and disposal of damage assets was not carried out. Meanwhile, according to the UK Audit Commission (2000), there are three main problems and risks faced by local authorities as frequently being reprimanded in audit review. First, local authorities run the risk of wasting money on assets that are not required to meet service needs or are unnecessarily costly to run. Second, local authorities not serving the public well because building are of poor physical quality or make services difficult to access. Third, local authorities are missing opportunities to share property with other public agencies which would increase customer convenience.

According to Auditor General's Report Terengganu States (2013), all government assets shall be used and managed efficiently and systematically to reduce wastage, cost saving, increase asset life, prevent misuse and prevent asset from lost. To accomplish this aim, implementation of a project that involves immovable properties should be designed carefully to avoid wastage and maximize gains. However, various constraint exist in the management and maintenance of assets as reported by Local Government Department (2009) such as maintenance issues due to third class mentality, economy crisis, lack of efficiency in asset management and inexpediences officers in local authorities. For instance, the constructions of high value facilities without being utilized were causing an enormous waste of money. Therefore, meticulous planning should be implemented to ensure that value for money is obtained for any money that has been spent either from council funds or states and federal government allocation.

\section{Material and Methodology}

This study employs content analysis that allows researchers to understand social reality in a subjective but scientific manner (Zhang and Wildemuth, 2009). This study focus on factors that led to the loss of profit revenue from immovable asset projects and the improvement strategies that needs to be taken. About 33 Auditor General's Report of the 11 states in Peninsular Malaysia were identified from 2011 to 2013. Copies of the report were obtained through of the 11 states in official portal of Malaysian National Audit Department. However, the final samples for analysis only consist of 10 reports. This 10 report consists of 13 selected projects involved immovable assets managed by the council and can be a source of income to the council's revenue. The 13 selected projects are as table 2 follows: 


\section{Macrothink}

Table 1. Name of 13 selected project or activity

\begin{tabular}{|c|c|c|}
\hline No & Project & Name of audited project or activity \\
\hline 1 & $\mathrm{P} 1$ & Commercial Development Project of Pontian District Council, Johor (2011). \\
\hline 2 & $\mathrm{P} 2$ & Parking Management of Alor Setar City Council, Kedah (2011). \\
\hline 3 & P3 & $\begin{array}{l}\text { Public Amenities Management of Kubang Pasu District Council and Baling } \\
\text { District Council, Kedah (2011). }\end{array}$ \\
\hline 4 & $\mathrm{P} 4$ & $\begin{array}{l}\text { Public Facilities of Kota Bharu Municipal Council and Tumpat District Council, } \\
\text { Kelantan (2011). }\end{array}$ \\
\hline 5 & P5 & $\begin{array}{l}\text { Procument and Asset Management of Tapah District Council, Batu Gajah District } \\
\text { Council and Tanjung Malim District Council, Perak (2011). }\end{array}$ \\
\hline 6 & P6 & $\begin{array}{l}\text { Public Utilities Management of Manjung Municipal Council and Taiping } \\
\text { Municipal Council, Perak (2011). }\end{array}$ \\
\hline 7 & P7 & $\begin{array}{l}\text { Food Complexes and Public Markets Management of Penang Municipal Council, } \\
\text { Penang (2011). }\end{array}$ \\
\hline 8 & P8 & $\begin{array}{l}\text { Development project management of Batu Pahat Municipal Council and Kota } \\
\text { Tinggi District Council, Johor (2012). }\end{array}$ \\
\hline 9 & P9 & $\begin{array}{l}\text { Local Authority stall management of Mersing District Council and Tangkak } \\
\text { District Council, Johor (2012) }\end{array}$ \\
\hline 10 & P10 & $\begin{array}{l}\text { Stall and market management of Malacca Historical City Council and Hang Tuah } \\
\text { Jaya Municipal Council, Melaka (2012). }\end{array}$ \\
\hline 11 & P11 & Public Housing Schemes of Pulau Pinang Municipal Council, Penang (2012). \\
\hline 12 & P12 & $\begin{array}{l}\text { Procurement Management of Johor Bahru City Council and Simpang Renggam } \\
\text { District Council, Johor (2013). }\end{array}$ \\
\hline 13 & P13 & $\begin{array}{l}\text { Procurement Management of Dungun Municipal Council and Hulu Terengganu } \\
\text { District Council, Terengganu (2013). }\end{array}$ \\
\hline
\end{tabular}

\section{Result}

The audit carried out on performance management revealed several weaknesses in planning, implementing and monitoring by local authorities. Analysis on 13 local authorities project focused on what factors caused this organization suffered a loss in value and incapable to generate lucrative returns from projects. Table 1 below show seven main factors or issues emphasized by the auditor related to the mismanagement of immovable projects causing a lot of money being wasted: 
Table 2. Factor cause loss of value from local authorities' immovable project as audit remark

\begin{tabular}{|c|c|c|c|c|c|c|c|c|c|c|c|c|c|}
\hline $\begin{array}{l}\text { Audit remark on } \\
\text { value for money }\end{array}$ & $\mathrm{P} 1$ & $\mathrm{P} 2$ & P3 & P4 & P5 & P6 & P7 & P8 & P9 & P10 & P11 & P12 & P13 \\
\hline $\begin{array}{c}\text { Rental or tax } \\
\text { arrears }\end{array}$ & $\sqrt{ }$ & $\sqrt{ }$ & $\sqrt{ }$ & & $\sqrt{ }$ & & $\sqrt{ }$ & $\sqrt{ }$ & $\sqrt{ }$ & $\sqrt{ }$ & $\sqrt{ }$ & $\sqrt{ }$ & $\sqrt{ }$ \\
\hline $\begin{array}{l}\text { Problem of poor } \\
\text { maintenance }\end{array}$ & & & $\sqrt{ }$ & $\sqrt{ }$ & $\sqrt{ }$ & $\sqrt{ }$ & $\sqrt{ }$ & & $\sqrt{ }$ & $\sqrt{ }$ & $\sqrt{ }$ & $\sqrt{ }$ & $\sqrt{ }$ \\
\hline $\begin{array}{l}\text { Vandalism and } \\
\text { theft }\end{array}$ & & & $\sqrt{ }$ & & $\sqrt{ }$ & $\sqrt{ }$ & $\sqrt{ }$ & & $\sqrt{ }$ & & $\sqrt{ }$ & & $\sqrt{ }$ \\
\hline Delay of project & $\sqrt{ }$ & & & & $\sqrt{ }$ & & & $\sqrt{ }$ & & $\sqrt{ }$ & & $\sqrt{ }$ & \\
\hline $\begin{array}{l}\text { Poor } \\
\text { documentation, } \\
\text { record and system }\end{array}$ & $\sqrt{ }$ & $\sqrt{ }$ & & & $\sqrt{ }$ & $\sqrt{ }$ & & & $\sqrt{ }$ & $\sqrt{ }$ & $\sqrt{ }$ & $\sqrt{ }$ & \\
\hline $\begin{array}{l}\text { Asset remain } \\
\text { abandoned/cannot } \\
\text { be utilized }\end{array}$ & & & $\sqrt{ }$ & $\sqrt{ }$ & $\sqrt{ }$ & & $\sqrt{ }$ & $\sqrt{ }$ & & & & $\sqrt{ }$ & $\sqrt{ }$ \\
\hline $\begin{array}{l}\text { Weak enforcement } \\
\text { by the council }\end{array}$ & $\sqrt{ }$ & & & & & & & $\sqrt{ }$ & $\sqrt{ }$ & $\sqrt{ }$ & $\sqrt{ }$ & & \\
\hline
\end{tabular}

Main factor affecting a lot of money being wasted was arrears in rental or tax from immovable property. Main purpose of rent and tax imposed to immovable property is to generate financial resources of local authorities. Auditor found high rental arrears on property were caused by delayed project, idle completed property, incomplete information on property and rental, no enforcement action on outstanding rental cases and none application system on tenancy record. For example, project delays hinder rental and property tax collection. Rental collection has also been affected when completed project remain vacant and not be utilized.

Auditor also discovered a lot of projects were not utilized such as business complex, public market, playground, community hall, retail complex, food court, public toilet, quarters, bus stop and stall. These projects were funded by the local authorities or state and federal government allocation. Such property or assets have the sole purpose of providing the needed services to the public and to enhance local authorities' revenue. Since these projects involved a lot of money, local authorities must ensure the returns commensurate with the value that has been spent. The local authorities' financial problem can be overcome by solving problems of idle building and business complex. These assets were idle as they received poor response from potential tenant, non strategic location of property, small retail space, competition with existing private retail space, lack of promotion and poor maintenance. Supposedly, factors like the suitability of the location, future prospects and local community need have been well considered at the planning stage as to assure financial gain upon the completion of the projects.

The continuity of idle project resulted to property damages. Unused properties have been vandalized and stolen as there was no early monitoring and serious enforcement by the local 
authorities' staff. The damage will be more severe if the property left longer. Besides no revenue can be generated, a lot of money needs to be provided to fix the damages. The maintenance of property that has been neglect for years requires large amount of funds. Based on one review case, council spent large sums of money on service security to avoid vandalism and thefts activities on idle property. Moreover, weak enforcement on idle project may cause to illegal activities. Council also suffered loss of money from delayed projects. One of factors that caused project delay was the developers' financial problem. Audit review found the developer did not submit detail development proposals and their financial background to local authorities. In one case, no penalties on delayed project have been imposed.

In order to avoid recurring weaknesses of local authorities' property, thus the measures listed in table 3 is recommended the audit to be considered by local authorities:

Table 3. Audit Recommendation to improve the management of the property

\begin{tabular}{|c|c|l|l|}
\hline No & Factor/Issue & \multicolumn{1}{c|}{ Auditor Recommendation } \\
\hline 1 & $\begin{array}{c}\text { Rental or tax } \\
\text { arrears }\end{array}$ & $\begin{array}{l}\text { The audit highlighted the need of tenancy agreement. Besides, the councils } \\
\text { should intensify efforts to collect current stall rental arrears in order to } \\
\text { prevent escalating rental arrears in the near future. Local authorities could } \\
\text { set a target in reducing outstanding rentals as a Key Performance Indicator } \\
\text { (KPI). Enforcement and effective legal action also should be taken against } \\
\text { tenant with long period of outstanding rentals. Most important is council } \\
\text { must ensure that the retail space have potential and received well respond } \\
\text { from tenants to avoid idle property as it affects uncollectible rent. }\end{array}$ \\
\hline 2 & $\begin{array}{c}\text { Problem of } \\
\text { poor } \\
\text { maintenance }\end{array}$ & $\begin{array}{l}\text { Audit highlighted to prepare and carry out maintenance plan periodically, } \\
\text { not reactive maintenance. The audits also suggest privatizing on } \\
\text { maintenance work. }\end{array}$ \\
\hline $\begin{array}{c}\text { Vandalism and } \\
\text { theft }\end{array}$ & $\begin{array}{l}\text { Vandalism and theft occur when idle property is left without supervision. } \\
\text { Therefore, the property that is still not in operation should not be left } \\
\text { unattended. }\end{array}$ \\
\hline $\begin{array}{c}\text { Delay of } \\
\text { project }\end{array}$ & $\begin{array}{l}\text { Important consideration regarding feasibility study for establishing each } \\
\text { asset must be examined in every aspect such as developer's qualification, } \\
\text { commensurate return, level of property necessity, site suitability and } \\
\text { document of agreement. Audit recommended that during initial pre-project } \\
\text { preparation remains, local authorities must analyze well on the expertise } \\
\text { and ability of developers and ensure the creation of property is in line with } \\
\text { the needs of public. In addition, during the construction phase, a special } \\
\text { committee must be set up to monitor the project continuously so that } \\
\text { property could be complete as schedule. Local authorities should also seek } \\
\text { the views and comment of the state legal advisor on actions to against the } \\
\text { companies. }\end{array}$ \\
\hline $\begin{array}{l}\text { Audit highlighted the local authorities would be able to manage their assets } \\
\text { efficiently with a better documentation, records, and system related to }\end{array}$ \\
\hline
\end{tabular}




\begin{tabular}{|c|c|l|l|}
\hline $\begin{array}{c}\text { record and } \\
\text { system }\end{array}$ & $\begin{array}{l}\text { property information. For example, local authorities should update the } \\
\text { rental application schedule and undertake schedule maintenance. }\end{array}$ \\
\hline $\begin{array}{c}\text { Asset remain } \\
\text { abandoned/ } \\
\text { cannot be } \\
\text { utilized }\end{array}$ & $\begin{array}{l}\text { In general, local authorities are advised to carefully plan for building and } \\
\text { facilities creation thus the assets could be beneficial for the public and } \\
\text { local authorities themselves. Local authorities should conduct a } \\
\text { preliminary study on site suitability, prospecting for income and public } \\
\text { response before embarking on development projects so as to avoid stalls } \\
\text { and retail complexes built not getting response for rental. In addition, more } \\
\text { effective promotion such as announcements and advertisements in public } \\
\text { places should be carried out. The audit recommends to privatising the } \\
\text { property that are not utilised to those interested in its development. Next, } \\
\text { one mechanism to deal with this problem is by changing the use of } \\
\text { property from the original purpose. }\end{array}$ \\
\hline 7 & $\begin{array}{l}\text { Council should take enforcement action against tenants who breach the } \\
\text { rental agreement, the traders who are doing business without license and } \\
\text { the tenants who fail to settle the stall rental. Council is advised to carry out } \\
\text { enforcement by } \\
\text { the council } \\
\text { scheduled monitoring to all property to overcome the problem of project } \\
\text { delay, vandalism, invasion and theft on property and misappropriation } \\
\text { property }\end{array}$ \\
\hline
\end{tabular}

Source: Edited from 13 selected projects of Auditor General Report of State Government Department (2014)

\section{Conclusion and Recommendation}

This paper presents the content analysis result on management of local authorities immovable property projects reported in 10 Auditor General's Reports from 2011-2013. Analysis revealed that the factors which have led to waste of money were interrelated to each other. The correlation between those factors described the difficulties faced by local authorities in managing their immovable property to achieved value for money. The results showed that the loss of profits and the waste of money were due to the failure of utilizing property management in local authorities a valuable source of revenue. A lot of money invested for buildings and facilities construction project have been wasted, thus unprofitable to the local authorities. Therefore, local authorities should adopt property marketing strategies as practiced by private developers to ensure that the property is managed towards value for money. Improvements to the administration and management especially on council's immovable property are able to reduce the financial problems of local authorities in Malaysia. For further research, it is recommended that property management weaknesses of local authorities were explained by categories such as type of property, usage and resource allocation.

\section{References}

Audit Commission. (1988). Local Authority Property, A Management Overview, Her Majesty’s Stationery Office (HMSO), London. 


\section{Mll Macrothink}

Journal of Management Research ISSN 1941-899X 2015, Vol. 7, No. 2

Audit Commission. (2000). Hot property, getting the best from local authority asset. Audit Commission for Local Authorities and National Health Service in England and Wales.

Auditor General's Report of Perak State. (2011). The Activities of the Perak State Government Departments and Agencies and the Management of State Government Companies. Retrieved from https://www.audit.gov.my/

Auditor General's Report Terengganu States. (2013). The Activities of the Terengganu State Government Departments and Agencies and the Management of State Government Companies. Retrieved from https://www.audit.gov.msy/

Bovaird T. dan Loffler E. (2002). Moving From Excellence Model Of Local Service Delivery To Benchmarking 'Good Local Governance', International Review of Administrative Sciences, 68, 9-4. http://dx.doi.org/10.1177/0020852302681001

Constantin, et al. (2011). Classification Criteria Used as Basis for An Effective Municipal Property Management. The $51^{\text {st }}$ Congress of European Regional Science Association. Barcelona, Spain.

Danilah, S., \& Siti Nabihah, A. K. (2011). Accountability Practice at Local Government of Malaysia. $2^{\text {nd }}$ International Conference on Business and Economic Research Proceedings, Langkawi, Kedah, Malaysia.

Dent, P. (2002). Modernising government: a new way to manage property assets? FIG XXII International Congress. Washington, D. C.,USA.

Ghobadian, A., \& Ashworth, J (1994), Performance Measurement in Local governmentConcept $\mathrm{n}$ Practice. International Journal of Operations and Production Management, 14(5), 35-51. http://dx.doi.org/10.1108/01443579410056786

Jolicoeur, P. W., \& Barret, J.T. (2004). Coming of Age, Strategic Asset Management in the Municipal Sector, Journal of facilities management 3(1), 41-52. http://dx.doi.org/10.1108/14725960510808383

Local Government Department. (2009). Ucaptama Pengurusan Aset Pihak Berkuasa Tempatan. Bengkel Pengurusan Aset PBT, Kota Kinabalu, Sabah.

Nafsiah Mohamed and Ruhaya Atan. (2006). Financial Performance of Local Authorities with Emphasis of Deficits. The Proceedings of International Conference on Local Government, Kota Kinabalu, Sabah.

National Audit Department. (2007). Emerging Issues and Global Challenges in the Public Sector Audit in the $21^{\text {st }}$ Century-Malaysian Perspectives. Seminar on Public Sector Audit, Jakarta, Indonesia

National Audit Department. (2011). Public Asset Management in Malaysia, an Audit Perspective, $1^{\text {st }}$ World Congress and Exhibition Infrastructure Asset Management, PWTC Kuala Lumpur.

Phelps, A. P. (2009). An Examination Of The Relationship Between Rationale, Practice And 


\section{Macrothink}

Journal of Management Research

ISSN 1941-899X 2015, Vol. 7, No. 2

Outcomes In Municipal Property Asset Management, A Comparative Study Of The UK And Russia. Doctoral Thesis, International Development Department School of Government And Society, University Of Birmingham.

Ruhaya Atan et al. (2010). Financial Performance of Malaysian Local Authorities, a Trend Analysis. International Conference on Science and Social Research (CSSR), Kuala Lumpur, Malaysia.

Soeb Pawi, Juanil D. M., \& Wan Zahari Wan Yusoff. (2011). Property Tax Management Model of Local Authorities in Malaysia. Proceeding of the International Conference on Social Science, Economics and Art. Putrajaya, Malaysia.

Thenmolli Vadeveloo and Kuppusamy Singaravelloo. (2013), Kerajaan Tempatan dan Pembangunan Masyarakat: Satu Perspektif Teori. International Conference on Social Science Research. (ICSSR), Penang, Malaysia.

Zhang, Y., \& Wildemuth, B. (2009). Qualitative analysis of content. In B. Wildemuth (Ed.), Applications of social science research methods to questions in library and information science. Englewood, CO: Libraries Unlimited.

\section{Copyright Disclaimer}

Copyright for this article is retained by the author(s), with first publication rights granted to the journal.

This is an open-access article distributed under the terms and conditions of the Creative Commons Attribution license (http://creativecommons.org/licenses/by/3.0/). 